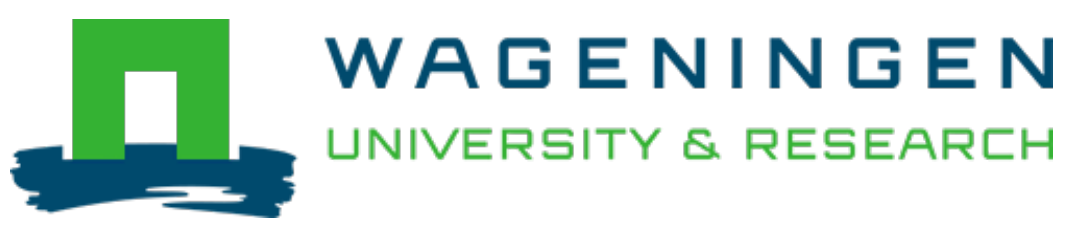

\title{
Active citizenship for urban green infrastructure : fostering the diversity and dynamics of citizen contributions through mosaic governance
}

\author{
Current Opinion in Environmental Sustainability \\ Buijs, Arjen E.; Mattijssen, Thomas J.M.; Jagt, Alexander P.N.; Ambrose-Oji, Bianca; Andersson, Erik et al \\ https://doi.org/10.1016/j.cosust.2017.01.002
}

This article is made publicly available in the institutional repository of Wageningen University and Research, under the terms of article $25 \mathrm{fa}$ of the Dutch Copyright Act, also known as the Amendment Taverne. This has been done with explicit consent by the author.

Article 25 fa states that the author of a short scientific work funded either wholly or partially by Dutch public funds is entitled to make that work publicly available for no consideration following a reasonable period of time after the work was first published, provided that clear reference is made to the source of the first publication of the work.

This publication is distributed under The Association of Universities in the Netherlands (VSNU) 'Article $25 \mathrm{fa}$ implementation' project. In this project research outputs of researchers employed by Dutch Universities that comply with the legal requirements of Article $25 \mathrm{fa}$ of the Dutch Copyright Act are distributed online and free of cost or other barriers in institutional repositories. Research outputs are distributed six months after their first online publication in the original published version and with proper attribution to the source of the original publication.

You are permitted to download and use the publication for personal purposes. All rights remain with the author(s) and / or copyright owner(s) of this work. Any use of the publication or parts of it other than authorised under article $25 \mathrm{fa}$ of the Dutch Copyright act is prohibited. Wageningen University \& Research and the author(s) of this publication shall not be held responsible or liable for any damages resulting from your (re)use of this publication.

For questions regarding the public availability of this article please contact openscience.library@wur.nl 


\section{Active citizenship for urban green infrastructure: fostering the diversity and dynamics of citizen contributions through mosaic governance Arjen E Buijs ${ }^{1,2}$, Thomas JM Mattijssen ${ }^{1}$, Alexander PN Van der Jagt ${ }^{3}$, Bianca Ambrose-Oji ${ }^{4}$, Erik Andersson ${ }^{1,2,3,4,5,6}$, Birgit HM Elands ${ }^{1}$ and Maja Steen Møller ${ }^{5}$}

\begin{abstract}
Active citizens may contribute to the environmental, social, and institutional resilience of cities. This review discusses how citizen initiatives protect biodiversity hotspots, contribute to social cohesion, institutional innovation, and diversity in urban green space management. Challenges related to social inclusiveness, ecological connectivity and continuity suggest government involvement is pertinent, but needs to be refocused. To maximise environmental outcomes of active citizenship, governments may adopt an enabling and stimulating governance style that harnesses the transformative potential of active citizenship. This paper argues for mosaic governance to work with the heterogeneous array of people, institutions, and spatial practices associated with active citizenship. Mosaic governance aims for a context-sensitive way of urban green infrastructure planning, enhancing relationships between the diversity of landscapes and communities across cities.
\end{abstract}

\footnotetext{
Addresses

${ }^{1}$ Forest and Nature Conservation Policy Group, Wageningen University, P.O. Box 47, 6700 AC Wageningen, The Netherlands

${ }^{2}$ Wageningen Environmental Research, Droevendaalsesteeg 3, 6708PB Wageningen, The Netherlands

${ }^{3}$ Centre for Ecosystems, Society and Biosecurity, Forest Research, Northern Research Station, Roslin EH25 9SY, United Kingdom

${ }^{4}$ Forest Research, c/o Forestry Commission, 620 Bristol Business Park, Coldharbour Lane, Bristol BS16 1EJ, United Kingdom

${ }^{5}$ Landscape Architecture and Planning, University of Copenhagen. Rolighedsvej 23, 1958 Frb. Copenhagen, Denmark

${ }^{6}$ Stockholm Resilience Centre, Stockholm University, Kräftriket, 10405 Stockholm, Sweden
}

Corresponding author: Buijs, Arjen E (arjen.buijs@wur.nl)

Current Opinion in Environmental Sustainability 2017, 22:1-6

This review comes from a themed issue on System dynamics and sustainability

Edited by Niki Frantzeskaki, Dagmar Haase, Michail Fragkias and Thomas Elmqvist

Received 21 June 2016; Revised 09 January 2017;

Accepted 11 January 2017

http://dx.doi.org/10.1016/j.cosust.2017.01.002

1877-3435/๑ 2017 Elsevier B.V. All rights reserved.

\section{Green space governance and active citizenship}

The contemporary rapid pace of urbanisation is putting pressure on green spaces in urban areas [1]. Despite this, citizens expect good living conditions, including access to urban green spaces. The concept of green infrastructure, as an interconnected network made up of a mosaic of different green spaces varying in character and ecology, focused public agencies attention on the potential of urban greenspaces, Urban Green Infrastructures may accommodate a range of human needs and provide ecosystem services that might increase urban social and ecological resilience.

The socio-cultural diversity of cities poses a challenge to the inclusive governance of urban green infrastructure [2]. Consequently, the need to adopt a multi-level, collaborative, and polycentric governance approach involving a diversity of actors and governance levels into decision-making is paramount $\left[3,4^{\circ \bullet}\right]$. Research suggests that such inclusive models improve governance outcomes, including environmental and social benefits [5] and the resilience of civil and governmental institutions [6]. In recent years, involvement of citizens in greenspace governance has developed from a focus on public participation in government policies towards increased active citizenship [7].

We understand active citizenship as citizens' ability to organize themselves in a multiform manner, to mobilize resources and to act in the public [ . . ] in order to protect rights and take care of common goods [8, p. 11]. Active citizenship usually does not start from government interventions but operates somewhat independently from public authorities. It is also referred to as self-organisation, self-governance, Do-It-Yourself democracy, or bottom-up governance. The engagement of citizens with local green spaces can be motivated by a combination of social and environmental objectives, rooted in a type of environmental stewardship that goes beyond immediate personal benefit and incorporates wider cultural values [9].

There are many socio-cultural and institutional reasons that may account for the increasing role of active citizens, 
including government retrenchment of central funding for services supplying public goods $[10,11]$. Some researchers have criticized attempts to mobilise citizens to compensate for government retreat as neoliberal governance techniques with little real shift in power from public agencies to local communities [12]. Indeed engagement processes can include implicit and explicit mechanisms that exclude some citizens from taking part. Active citizenship critically depends on cultural capital, that is the capacity and capability of people to take part in actions around spaces they value [13]. As this capital is not distributed evenly across communities, retreating government initiatives can lead to unintended impacts on environmental justice and the fair distribution of access to public green space with selective participation by vocal and well organised interest groups in negotiation and management [14].

Our objective for this review is to synthesise evidence of how green active citizenship contributes to the resilience of cities and urban areas and how governance processes may relate to the complexity and diversity of active citizenship. We use the term resilience to mean the ability of urban systems to adapt and thrive in changing circumstances. The positive contributions of active citizenship come with a number of challenges, so our review ends by outlining a governance framework for tackling these while nurturing positive outcomes.

\section{Contributions to environmental, social and institutional resilience}

In discussing the contributions of active citizens to the quality of urban living, we focus on contributions of active citizenship to the environmental [15], institutional $\left[4^{\bullet \bullet}\right]$, and social $\left[16^{\circ \bullet}\right]$ resilience of cities, using examples from the literature as well as three 'good practice' cases from new research in three European cities [17].

\section{Environmental resilience}

Active citizenship has been demonstrated to contribute to environmental resilience through greenspace creation, restoration, enhancement and maintenance efforts $\left[18^{\bullet \bullet}\right]$. Such inputs to the quantity, quality and diversity of urban ecosystems are important drivers of urban resilience to natural hazards [15]. Reported benefits of active citizenship include the provision of regulatory ecosystem services [19], an increase in biodiversity and pollination [20], restoration of biodiversity and ecosystem services after natural disasters [21], and a decrease in $\mathrm{CO}_{2}$ emissions [22]. Active citizens often focus on maintenance of urban green. As such, they contribute to the on-going challenge for municipalities of place-keeping $\left[23^{\circ}\right]$, that is the resilient management of urban green spaces. Placekeeping is important resilient management of urban green spaces. Place-keeping is important to ensure the long-term continuity of stewardship that is required to preserve the social, environmental and economic values of a place [24]. Place-keeping is a continuous process aimed at sustained engagement of a diversity of stakeholders, including citizens [25]. For example, in the Dutch city of Amsterdam, active citizens of the nature association De Ruige Hof ('The Wild Court') have successfully been managing and safeguarding 13 hectares of green spaces against urban encroachment for over 30 years [17]. By adopting pieces of derelict land and managing this for nature conservation, including targeted biodiversity monitoring programs they have achieved improvements to biodiversity as indicated by the return of multiple red-listed species to the areas a result of habitat creation and conservation management.

Long term place-keeping by active citizens is particularly challenging given the voluntary nature of citizen contributions, and the degree to which citizens are equipped to take on these kinds of responsibilities [26]. Furthermore, volunteers can be prone to burnout [27], or the engagement may be short term or unreliable [14]. In addition, many such initiatives increasingly suffer from insecure funding and governmental budget cuts [e.g. 28].

Devolution and fragmentation of management of urban greenspace has also led to random emergence of unexpected outcomes at larger spatial scales. The small scale heterogeneity of urban land cover may result in loss of ecological connectivity [29,30]. To tackle this potential problem, initiatives from active-citizens need to be connected to other actors and projects [31]. Depending on the strength of the networks of active citizens and the ecological characteristics of the area, municipalities or NGO's may be needed to initiate such collaboration. However, tensions may exist between the autonomy of active citizen groups and active involvement of higherscale institutions to ensure connectivity [32].

\section{Institutional resilience}

Active citizenship has been shown to build several aspects of institutional resilience, that is the ability of governance systems to withstand and adapt to disturbance in the socio-ecological system [33]. This is mainly through encouraging a more polycentric governance system where active citizens complement other actors by providing local knowledge [42], as well as experimenting with innovative ideas $\left[4^{\bullet \bullet}, 34\right]$. The autonomous, disorganised and sometimes critical nature of civil society offers alternative ideas to addressing social and environmental problems [35]. An example of this is the dynamic urban agriculture concept developed by a social enterprise (Xenofilia) in Malmö (Sweden) [17] (Figure 1).

Responding to the challenge of urban expansion, whilst incorporating the economic objectives of developers, Xenofilia created temporary gardens on small areas of derelict land and dynamic agriculture on larger areas, supported by local community. As urban development 
Figure 1

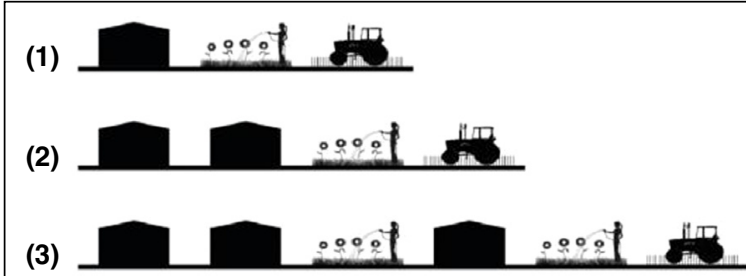

(1)

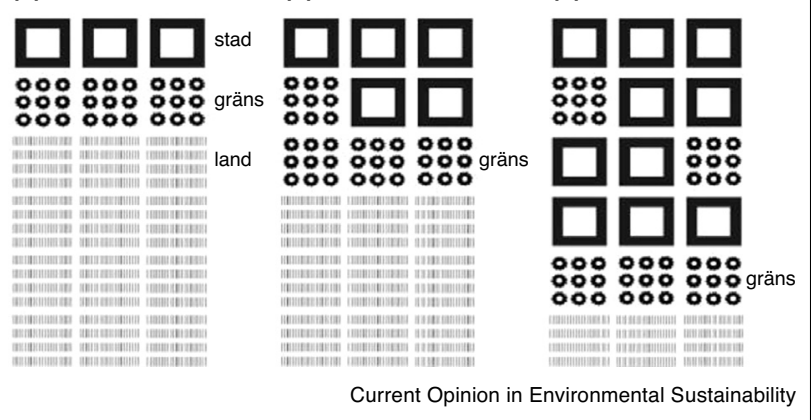

Hyllie, Malmö: institutional resilience through experimentation with dynamic green spaces.

progresses, some of the gardens will be turned into public parks and the farmland will gradually extend further landward as the city expands. The focus of the project is on creating and maintaining urban greenspace that can support employment as well as provide other ecosystem services. This example illustrates how involving nongovernmental actors can lead to innovative approaches to land use mixing spatial and temporal dimensions of place, and access to alternative funding streams, both of which may increase institutional resilience.

Multiple parallel processes and inclusion of additional decision making among heterogeneous interests high transaction costs, especially at larger scales and higher levels of governance $\left[4^{\bullet \bullet}\right]$. More dispersed governance may make accountability issues less transparent and shift power relations in unexpected ways $\left[4^{\bullet \bullet}\right]$.

\section{Social resilience}

Thirdly, active citizenship may increase the social resilience of cities and their inhabitants, that is the ability of groups or communities to cope with external stresses and disturbances as a result of social, political, and environmental change [16 ${ }^{\bullet}$; pp. 347]. By bringing people together and formulating shared goals, citizen groups are known to contribute to social cohesion [36]. Improved self-organisation through activities such as urban food growing can help citizens build resilience to declining economic conditions, and the promotion of environmental awareness and education [37]. Citizen groups can have better access to underprivileged communities such as ethnic minorities
[38], and can thus help in making greenspace governance more inclusive. A good example of the role of active citizenship in creating social resilience can be found in Edinburgh (United Kingdom) [17]. Granton Community Gardeners was started by local residents who wanted to improve the local neighbourhood through a period of financial austerity and build a sense of community in one of the most deprived areas of Edinburgh. After six years of operation they now manage 10 gardens on local authority land. The initiative operates independently of local government input. Active citizenship includes the provision of, and education about, healthy and nutritious food to residents and also provides an alternative to food banks for the most vulnerable. The gardens have also been important in positively changing the image of Granton. By engaging citizens from a wide range of ethnic and economic backgrounds to take part in communal cultivation, harvesting and cooking/eating projects cultural and local ecological knowledge exchange is supported [17], which may contribute to the building of urban conviviality, social integration, social and cultural capital.

\section{Mosaic governance to foster active citizenship}

The development of effective and integrated governance models for environmental sustainability is a key challenge in current times [39,40]. As we have shown, citizen engagement has a number of positive aspects to bring to the table but also challenges. The potential problems pointed to in the previous sections call for inclusive governance capable of drawing on the strengths of public participation while avoiding its undesired outcomes. Local to regional authorities seem to be logical partners to the citizen initiatives. Instead of a retreat of government, a change is needed towards a more enabling and stimulating governance approach that harnesses the transformative potential of active citizenship [ $\left.41^{\bullet \bullet}, 42,43\right]$. The physical diversity of urban greenspaces [44], the cultural diversity of urban citizens and their use of greenspaces [45] and the institutional diversity of how citizens selforganise [29] is not compatible with green space governance arrangements that are based on generic 'one-size fits all' municipal engagement policies. It requires reconsideration of what inclusive planning and governance is and needs to move away from the narrow focus of community involvement in formalised planning practices to embracing a broad range of partnerships, from supporting autonomously developed bottom-up initiatives right through to cross-sector partnerships [41 $\left.{ }^{\bullet \bullet}\right]$.

In our view, what is needed in this respect is recognition of governance that is sensitive to the diversity and dynamics of active citizenship and which aligns with local informal networks and across scales. We call this mosaic governance (Figure 2). Mosaic governance goes beyond polycentric governance, with its acknowledgement of the 
Figure 2

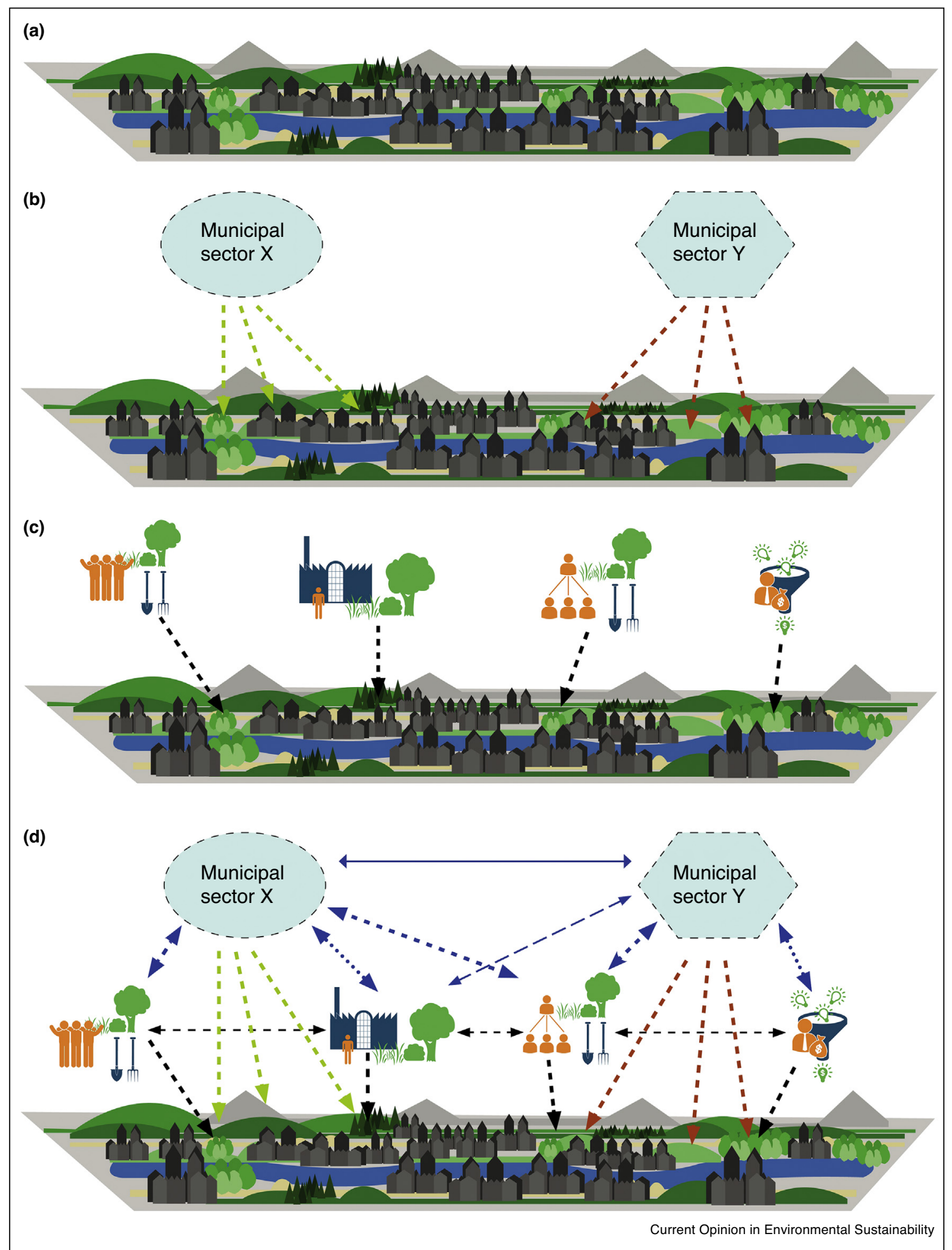

(a) Urban green infrastructure: urban green spaces are diverse but ecologically interdependent, often represented as a mosaic landscape. (b) Traditional municipal-led planning and management to enhance and maintain urban green infrastructure. (c) Independent contributions from active citizen groups to enhance and maintain local green spaces. (d) The challenge of developing mosaic governance to enhance horizontal and vertical integration of policy and active citizenship (in order) to enhance urban green infrastructure. The diversity in blue lines between municipal sectors and active citizens signifies the diversity in this relationship, dependent on, for example needs and demands from different types of citizen groups related to the institutional diversity of how citizens self-organise. 
diversity of actors and scales, and beyond landscape governance, with its acknowledgement of the spatial dimension of environmental government [46]. Mosaic governance demands a context-sensitive approach to planning, acknowledging relations and interdependencies not only between ecological and social scales, but also between the geographically distinct urban landscapes, community identities, and specific practices of active citizen groups across the city. Mosaic governance delivers resilience through arrangements that differ by greenspace type, by the character of the citizens that take part and varies through time in a way that bridges spatial and temporal boundaries of a site in response to changing social and ecological circumstances. Local authorities can provide some of the coordination of bottom-up initiatives that is needed to achieve well-connected, multifunctional urban green infrastructure, which is key to urban resilience [31,47]. A crucial challenge in mosaic governance is therefore to strike the right balance between acknowledging the autonomy of individual those on strengthening social and ecological connectivity between the full ranges of initiatives [17].

The concept of mosaic governance emphasises there is unlikely to be a single combination of governance instruments with optimal and resilient outcomes for both the environment and local people [48]. A number of recent literature reviews on the topic of urban greening and urban forestry [6,49-51] have highlighted the sparse and unsystematic nature of research detailing the diversity of governance arrangements and their associated impacts. Research which clearly and systematically reports on the multiple ways in which context (e.g. policies, available resources) and processes (e.g. evolving discourses, engagement techniques) combine to produce different types of governance outputs and outcomes [52 $2^{\circ \bullet}$, may well be able to demonstrate and convince public bodies and local authorities about benefits of adopting a mosaic governance approach.

\section{Acknowledgements}

This research was funded by the European Commission Seventh Framework Programme (FP7-ENV.2013.6.2-5-603567) and participating partners in the GREEN SURGE research project.

\section{References and recommended reading}

Papers of particular interest, published within the period of review, have been highlighted as:

- of special interest

$\bullet$ of outstanding interest

1. Haase D, Frantzeskaki N, Elmqvist T: Ecosystem services in urban landscapes: practical applications and governance implications. Ambio 2014, 43:407-412.

2. Buizer M, Elands B, Vierikko K: Governing cities reflexively - the biocultural diversity concept as an alternative to ecosystem services. Environ Sci Policy 2016.
3. Ostrom E: Beyond markets and states: polycentric governance of complex economic systems. Am Econ Rev 2010, 100:641-672.

4. Huitema D, Mostert E, Egas W, Moellenkamp S, Pahl-Wostl C,

- Yalcin R: Adaptive water governance: assessing the institutional prescriptions of adaptive (co-)management from a governance perspective and defining a research agenda. Ecol Soc 2009, 14.

This paper investigates how adaptive (co-)management can contribute to institutional resilience through four institutional prescriptions: collaboration in a polycentric governance system, public participation, an experimental approach to resource management, and management at the bioregional scale. The paper calls attention to the complexities associated with participation and collaboration and the difficulty of experimenting in a real-world setting.

5. Newig J, Fritsch O: Environmental governance: participatory, multi-level-and effective? Environ Policy Gov 2009, 19:197-214

6. McMillen H, Campbell LK, Svendsen ES, Reynolds R: Recognizing stewardship practices as indicators of social resilience: in living memorials and in a community garden. Sustainability (Switzerland) 2016, 8.

7. Hoskins B: Monitoring active citizenship in the European union: the process, the results and initial explanations. Cadmo 2009, 17:55-71.

8. Moro G: Citizens in Europe: Civic Activism and the Community Democratic Experiment. Dordrecht: Springer; 2012.

9. Krasny ME, Tidball KG: Civic ecology: a pathway for Earth Stewardship in cities. Front Ecol Environ 2012, 10:267-273.

10. Blanco I, Griggs S, Sullivan H: Situating the local in the neoliberalisation and transformation of urban governance. Urban Stud 2014, 51:3129-3146.

11. Buijs $A$, Mattijssen $T$, Arts $B$ : The man, the administration and the counter-discourse: an analysis of the sudden turn in Dutch nature conservation policy. Land Use Policy 2014, 38:676-684.

12. Lister M: Citizens, doing it for themselves? The big society and government through community. Parliam Affairs 2015, 68:352-370.

13. Putnam RD: Bowling Alone: The Collapse and Revival of American Community. New York: Simon \& Schuster; 2000.

14. Rydin Y, Pennington M: Public participation and local environmental planning: the collective action problem and the potential of social capital. Local Environ 2000, 5:153-169.

15. McPhearson T, Andersson E, Elmqvist T, Frantzeskaki N: Resilience of and through urban ecosystem services. Ecosyst Serv 2015, 12:152-156.

16. Adger WN: Social and ecological resilience: are they related? -. Progr Hum Geogr 2000, 24:347-364.

This article argues a clear link exists between social and ecological resilience. It examines whether resilience is a useful characteristic for describing the social and economic situation of social groups and explores potential links between social resilience and ecological resilience.

17. Buiis A, Elands B, Havik G, Ambrose-Oji B, Gerőházi E, Jagt AVd, Mattijssen T, Møller MS, Vierikko K: Innovative Governance of Urban Green Spaces. Learning from 18 Innovative Examples Across Europe. Wageningen: Wageningen University; 2016.

18. Colding J, Barthel S, Bendt P, Snep R, van der Knaap W,

-. Ernstson H: Urban green commons: insights on urban common property systems. Global Environ Change 2013, 23:1039-1051. This paper discusses the role of urban green commons, or publicly owned green spaces, in biodiversity conservation in urban settings. There are many bundles of rights related to these spaces, and they can provide several important benefits. The authors identify urban green commons as having a key role in transforming cities towards better social and ecological environments and discuss associated political questions.

19. Krasny ME, Russ A, Tidball KG, Elmqvist T: Civic ecology practices: participatory approaches to generating and measuring ecosystem services in cities. Ecosyst Serv 2014, 7:177-186. 
20. Dennis $M$, James $P$ : User participation in urban green commons: exploring the links between access, voluntarism, biodiversity and well being. Urban For Urban Green 2016, 15:22-31.

21. Chan J, DuBois B, Tidball KG: Refuges of local resilience: community gardens in post-Sandy New York City. Urban For Urban Green 2015, 14:625-635.

22. Barthel S, Parker J, Ernstson H: Food and green space in cities: a resilience lens on gardens and urban environmental movements. Urban Stud 2015, 52:1321-1338.

23. Dempsey N, Burton M: Defining place-keeping: the long-term

- management of public spaces. Urban For Urban Green 2012, 11:11-20.

This book presents the latest research and practice on place-keeping, or the long-term management of open space. It discusses important aspects in e.g. policy, governance, management and financing of place-keeping and how this relates to the maintenance of high-quality public spaces.

24. Fors H, Molin JF, Murphy MA, Konijnendijk van den Bosch C: User participation in urban green spaces - for the people or the parks? Urban For Urban Green 2015, 14(3):722-734.

25. Burton M, Mathers A: Collective responsibility for placekeeping: are partnerships the solution for open space management? Place-Keeping: Open Space Management in Practice. New York: Routledge; 2014, 76-99.

26. Smith H, Pereira M, Hull A, Konijnendijk van den Bosch C: The governance of open space: decision-making around place-keeping. Place-Keeping: Open Space Management in Practice. New York: Routledge; 2014, 52-75.

27. Byron I, Curtis A: Landcare in Australia: burned out and browned off. Local Environ 2001, 6:311-326.

28. Johnson AE: Money matters: financial flows and priority setting around podocarpus national park, Ecuador. J Sustain For 2009 28:712-734.

29. Mattijssen TJM, Buijs AE, Elands $B, H M$, Arts $B$ : The green and self in green self-governance: a study of 264 green citizen initiatives and their objectives, activities and organization (in preparation).

30. Andersson E, Enqvist $\mathrm{T}$, tengö $\mathrm{M}$ : Stewardship in urban landscapes. In The Science and Practice of Landscape Stewardship. Edited by Bieling C, Plieninger T. Cambridge Univ. Press; 2017. (in press).

31. Franklin A, Marsden T: (Dis)connected communities and sustainable place-making. Local Environ 2015, 20:940-956.

32. Adams D, Scott AJ, Hardman M: Guerrilla warfare in the planning system: revolutionary progress towards sustainability? Geogr Ann Ser B Hum Geogr 2013, 95:375-387.

33. Herrfahrdt-Pähle E, Pahl-Wostl C: Continuity and change in social-ecological systems: the role of institutional resilience. Ecol Soc 2012, 17.

34. Gupta J, Termeer C, Klostermann J, Meijerink S, van den Brink M, Jong P, Nooteboom S, Bergsma E: The Adaptive Capacity Wheel: a method to assess the inherent characteristics of institutions to enable the adaptive capacity of society. Environ Sci Policy 2010, 13:459-471.

35. Buijs AE, Mattijssen T, Elands B: The meaning of green self-governance for Dutch nature management practices. Landschap (3):2016:133-140.

36. Veen EJ: Community Gardens in Urban Areas: A Criticial Reflection on the Extent Too Which They Strengthen Social Cohesion and Provide Alternative Food. Wageningen: Wageningen University and Research Centre; 2015, 265.

37. Camps-Calvet M, Langemeyer J, Calvet-Mir L, Gómez-Baggethun E, March $\mathrm{H}$ : Sowing resilience and contestation in times of crises: the case of urban gardening movements in Barcelona. Partecip Confl 2015, 8:417-442.
38. Elands BHM, Wiersum KF, Buijs AE, Vierikko K: Policy interpretations and manifestation of biocultural diversity in urbanized Europe: conservation of lived biodiversity. Biodivers Conserv 2015, 24(13):3347-3366

39. Bennett EM, Cramer W, Begossi A, Cundill G, Díaz S, Egoh BN Geijzendorffer IR, Krug CB, Lavorel S, Lazos E et al.: Linking biodiversity, ecosystem services, and human well-being: three challenges for designing research for sustainability. Curr Opin Environ Sustain 2015, 14:76-85.

40. Biermann F, Abbott K, Andresen S, Bäckstrand K, Bernstein S, Betsill MM, Bulkeley H, Cashore B, Clapp J, Folke C et al. Transforming governance and institutions for global sustainability: key insights from the Earth System Governance Project. Curr Opin Environ Sustain 2012, 4:51-60.

41. Hajer M, Nilsson M, Raworth $\mathrm{K}$, Bakker $\mathrm{P}$, Berkhout $\mathrm{F}$, de Boer $\mathrm{Y}$

- Rockström J, Ludwig K, Kok M: Beyond cockpit-ism: four insights to enhance the transformative potential of the sustainable development goals. Sustainability (Switzerland) 2015, 7:1651-1660

This papers argues that in current networking society, government ability to deliver public goods such as sustainability is declining. It argues for the interconnectedness of social and environmental concerns and claims that governments need to align with the "the energetic society" to benefit from the willingness of a broad group of actors to contribute to sustainable development goals.

42. Van der Steen M, Van Twist M, Chin-A-Fat N, Kwakkelstein T: Pop-up Public Value. Public Governance in the Context of Civic Self-organisation. The Hague: Netherlands School of Public Administration; 2013.

43. Wolfram M, Frantzeskaki N: Cities and systemic change for sustainability: prevailing epistemologies and an emerging research agenda. Sustainability (Switzerland) 2016, 8.

44. Kabisch N, Qureshi S, Haase D: Human-environment interactions in urban green spaces - a systematic review of contemporary issues and prospects for future research. Environ Impact Assess Rev 2015, 50:25-34.

45. Kloek ME: Colourful green: immigrants' and non-immigrants recreational use of greenspace and perceptions of nature. Forest and Nature Policy Group. Wageningen: Wageningen University; 2015, 146.

46. Buizer M, Arts B, Westerink J: Landscape governance as policy integration 'from below': a case of displaced and contained political conflict in the Netherlands. Environ Plann C Govern Policy 2015, 34:448-462.

47. Davies C, Hansen R, Rall E, Pauleit S, Lafortezza R, Bellis YD, Santos A, Tosics I: Green Infrastructure Planning and Implementation. The Status of European Green Space Planning and Implementation Based on an Analysis of Selected European City-Regions. Copenhagen: Green Surge Deliverable 5.1; 2015.

48. Brondizio ES, Ostrom E, Young OR: Connectivity and the governance of multilevel social-ecological systems: the role of social capital. Annu Rev Environ Resour 2009, 34:253-278.

49. Bentsen $\mathrm{P}$, Lindholst $\mathrm{AC}$, Konijnendijk van den Bosch $\mathrm{C}$ : Reviewing eight years of urban forestry: taking stock, looking ahead. Urban For Urban Green 2010, 9.

50. Krajter Ostoić S, Konijnendijk van den Bosch CC: Exploring global scientific discourses on urban forestry. Urban For Urban Green 2015, 14:129-138.

51. Lawrence A, De Vreese R, Johnston M, Konijnendijk van den Bosch CC, Sanesi G: Urban forest governance: towards a framework for comparing approaches. Urban For Urban Green $2013,12: 464-473$

52. Lawrence A, Ambrose-Oji BV: Beauty, friends, power,

- money: navigating the impacts of community woodlands Geogr J 2015, 181:268-279.

A UK-focused review touching upon the impacts of community forestry based on nearly 700 cases. One of the conclusions is that current studies on this topic are output focused, and need to consider more the less tangible outcomes, particularly related to community empowerment. 